\title{
How to Thrive in Turbulent Business Environments: Case Colombia's Mobile Telephony Industry
}

\author{
Hugo-Alberto Rivera-Rodríguez \\ Doctorado En Economia de la empresa Universidad de Valladolid. Spain \\ School of Management, Universidad del Rosario, Bogotá. Colombia \\ Calle 200 entre Autopista Norte y carrera 7 \\ Teresa Garcia-Merino \\ Departamento de Organización de Empresas y CIM, \\ Universidad de Valladolid. Spain \\ Valle Santos-Alvarez \\ Departamento de Organización de Empresas y CIM, \\ Universidad de Valladolid. Spain
}

Doi:10.5901/mjss.2017.v8n3p133

\section{Abstract}

Coevolution originated as a biological concept has traditionally been associated with the biological sciences to describe those cases of mutual evolutionary influence involving two (or more) species. This concept is fairly new in the study of organizations as it was introduced only two decades ago, specifically refers to a process involving successive changes between businesses and the environment. More recentrly, researchers began to employ the coevolution as an alternative to overcome the business turbulence with great success that would otherwise put its existence at risk. This article delimits the organizational coevolution concept making a direct association with business turbulence. It is being presented in the form of a multiple-case study of the mobile telephony industry in Colombia with a qualitative methodology. As part of the information-gathering process, approximately 300 public and private documents were consulted and 50 interviews with key stakeholders of the industry were conducted. Content analysis is the main data analysis technique, and the ATLAS/ti is used for processing. Thus, the final results show that when a sector faces turbulence, businesses can efficiently manage this phenomenon if they undertake a structural coupling process between the turbulent environment and strategic behaviour.

Keywords: Business turbulence, case study, mobile telephony, strategic behaviour, coevolution.

\section{Introduction}

Business turbulence is actively researched in the business management literature (Emery and Trist, 1965; Terreberry, 1968; Khandwalla, 1972, 1976/1977; Grant, 2003; Zúñiga-Vicente and Vicente-Lorente, 2006; Wu, He, and Duan, O'Regan, 2012; Tsai and Yang, 2014; Wang, 2015; Stieglitz, Knudsen and Becker, 2016). These authors frequently suggest theoretical alternatives to address turbulence with the notion that the environment affects performance both positively and negatively. Although these proposals have contributed to the recovery of some businesses, others have fallen off the path of growth and were liquidated.

This process involving simultaneous change is known as coevolution. Although this concept is not new to the business management literature (Eisenhardt and Galunic, 2000; Christensen, Schmidt and Larsen, 2003; Lampel and Shamsie, 2003; Flier, Van Den Bosch, and Volberda, 2003; Selsky, Goes and Babüroglu, 2006; Stead and Stead, 2013; Ramírez and Selsky, 2014; Abatecola, 2014; Pontikes and Barnett, 2016), it has recently been shown that companies that are managing turbulence tend to generate new organisational structures capable of modifying their behaviour. As a result, both the environment and the industry undergo metamorphoses that are necessary for businesses to grow. 
Considering the difficulty of representing coevolution that is related to the confusion in its application to companies and the necessity of gathering information regarding organisational action an exploratory qualitative study is undertaken aiming to investigate the coevolution relationship between a turbulent environment and businesses' strategic behaviour. This study is conducted in the Colombian mobile telephony industry as it is experiencing some turbulence. The main research findings reflect a structural coupling process between a turbulent environment and strategic behaviour that nonetheless allows for industry growth despite the turbulence.

\section{Literature Review}

\subsection{The concept of turbulence}

The origins of the term turbulence in the management literature date back to Emery and Trist (1965), who used the term to describe a property of an environment characterised by an exchange rate or other type of instability in its underlying factors that forces businesses to react. Thereafter, various authors paved the way to revitalising these ideas and began writing about the concept of turbulence (Galbraith, 1973; Duncan, 1972; Khandwalla, 1976/1977). These studies remained relatively unnoticed until Ansoff (1979) posited that turbulence is management's raison d'etre and that the leader should manage those surprises and discontinuities related to this condition.

Some researchers rapidly analysed the components and determinants of turbulence (Dess and Beard 1984; Chakravarthy, 1997; Grant, 2003; Head, 2005; Caldart and Ricard, 2006). In a literature review, Rivera (2010) acknowledges nearly 200 documents in only a 50 -year period that address turbulence. This review highlights the works written by Emery and Trist, 1965; Terreberry, 1968; Khandwalla 1972; Ansoff, 1979; McCann and Selski, 1984, D'Aveni 1994, and Gueguen, 2001. In recent years, interest in the subject has reappeared, including the following articles: Zhang, Jiang and Zhu, 2015; Wilden and Gudergan, 2014; Tsai and Yang; Liu, 2013; Hung and Chou, 2013; and Su, Peng, Shen and Xiao, 2013.

The review undertaken seems to indicate that business turbulence refers to a state of unrest in the environment. This state emerges as the result of changes in political, economic, social, technological, ecological and legal factors that simultaneously produce dynamism, uncertainty and complexity in a sector. To face this situation, organisations make decisions that might modify their strategic behaviour.

The effects of strategic behaviour on turbulence might lead to a new line of research that appears because interactions between the environment and businesses are traditionally explained bidirectionally: the environment can affect business behaviour and performance just as businesses can influence the environment's behaviour and performance. In addition, the literature intuits a relation involving reciprocal influence between turbulence and strategic business behaviour. The two parties reciprocally and simultaneously present metamorphoses that contribute to their evolution. From this perspective, coevolution is the explanatory principle for the environment-organisation relationship.

\subsection{The concept of coevolution}

The concept of coevolution has traditionally been associated with the biological sciences to describe those cases of mutual evolutionary influence involving two (or more) species. For years, this concept has been ignored in the field of organisational studies. Coevolution did not seem to apply to the field of business because the dominant premise in the environment-business relationship has been the existence of causal relationships. Nevertheless, over time, researchers cautiously noted coevolution as a concept that might be applicable to the business field. In fact, the first researchers to apply the coevolution concept to the business field were Baum and Singh (1994) and Kaufmann (1995), who stated that coevolution refers to a process involving successive changes between businesses and the environment.

With this starting point, empirical studies were undertaken that were consistent with one another in finding that the environment-business interaction generates new organisational forms. These forms affect business behaviour and, as a result, the environment suffers modifications in terms of clients, products, and governmental decisions (Barnett and Hansen, 1996; Van den Bosch, Volberda, and de Boer, 1999; Huygens, Baden-Fuller, Van den Bosch, and Volberda, 2001). Subsequently, researchers began to employ the coevolution concept when referring to rapid, competitive or turbulent environments (Huygens and others, 2001; Henderson and Stern, 2003; Christensen et al., 2003; Flier, Van Den Bosch, and Volberda, 2003; Lampel and Shamsie, 2003; Kuvalainen et al., 2004; Selskyet al., 2006; Caldart and Ricard, 2006; Breslin 2014a, 2014b; Schmitt, A., et al 2015).

Nevertheless - and despite advances in the subject - Porter (2006) indicates that inadequate understanding of the concept has generated inaccuracies when describing coevolutionary organisational processes. To rectify these 
inaccuracies, Porter followed Lewin and Volberda (1999) and proposed a series of coevolutionary characteristics specifically related to business management: a) Specificity: The evolution of an agent such that the environment or the business relies on selective pressures from some feature of the other agents of the system; $b$ ) Reciprocity: Changes in the business lead to changes in the environment, and vice-versa, which means that this repetitive interaction generates a circular causality and interdependence; c) Simultaneity: Features in both participants evolve concurrently; d) Multi-level: Coupling between the business and the environment leads companies to interact with new industries to implement business models; e) Multidirectional causalities: Parts of an organisation reciprocally coevolve in response to a change in the environment; f) History and development dependence: Adjustments between businesses and the environment are influenced by the level of knowledge and experiences accumulated in the past; and g) Learning: Business and the environment must increase their knowledge as a result of their mutual interaction.

Based on the previous discussions, coevolution might be understood as a simultaneous change process that accompanies environment-business interaction. This process implies successive and reciprocal changes in the environment and in businesses because the actions of one voluntarily or involuntarily directly affect those of the other, which leads to new changes and continues until there is no more reciprocity. At this juncture, the coevolutionary process culminates and the business and the environment again evolve independently.

\section{Empirical Application: Case of Mobile Telephony in Colombia}

The literature review provides evidence of the need to perform empirical studies. These studies should explore the coevolutionary relationship between turbulence and business strategic behaviour as a means of explaining turbulence management. The variables that control this relation are multidimensional and difficult to measure using standard procedures. Therefore, research should apply a flexible and holistic methodology to address all the aspects involved in turbulence management. In consideration of the foregoing, this study employs a qualitative methodology: the case-study data collection method. In addition, the study uses content analysis (CA) to gather and analyse data.

For Yin (2013), the case-study methodology should be used when the phenomenon studied is multidimensional (because the phenomenon must be analysed within its real life context), the research depends on a wide range of sources of evidence, and the study of the phenomena should be undertaken from different perspectives and should not be based on the influence of a single variable. The case study method is suited to analysing the phenomenon under specific circumstances because few empirical investigations explore the coevolutionary relationship between turbulence and strategic behaviour and a detailed analysis of the social elements present in the businesses must be undertaken.

The research technique selected has been CA, which is commonly used in qualitative case studies (Bowen, 2009) because it allows a thorough analysis to be performed from which a rich description of the phenomenon can be generated (Stake and Savolainen, 1995). This technique was chosen because it permits the analysis of human communication content spread through a range of documentary resources - written, audio, audio-visual or others - and it allows the researcher to gather, analyse and interpret information to recognise the basic dimensions of the phenomenon studied. (Bardin, 1986)

\subsection{Industry characterisation}

The mobile telephony industry in Colombia began operations in 1994 as a result of the demands of the economic opening process that began in 1989. This process required new and improved telecommunication services. Over the last two decades of operation, permanent changes in environmental factors have occurred, which have challenged the capacity of the businesses operating in the industry particularly during the first decade of the $21^{\text {st }}$ century - a period characterised by turbulence in the industry. The key milestones of the industry during this period consisted of the following:

$\checkmark$ Large multinational companies entered Colombia's mobile telephony market. Due to their investments in improved technology, new plans can be offered to users.

$\checkmark$ The emergence of a new operator broke the previously existing Comcel-Bellsouth duopoly.

$\checkmark$ The massification of mobile telephony and consumer migration from landline telephone service to mobile telephony - mainly to prepaid mobile telephony service. This massification led to customer heterogeneity, which led companies to offer products for different needs.

$\checkmark$ A combination of events, such as an increase in the number of users in the prepaid modality, price wars and a growth in the use of services for selling minutes, have generated a decline in average revenue per user (ARPU), which has forced operators to search for other sources of income, adopt cost reduction plans, search for new customers with more aggressive plans and increase income sources through additional services. 
$\checkmark$ The growth in the customer churn rate has continued because switching costs are low.

$\checkmark$ Continuous changes have occurred in terms of price regulations, control of competition and customer protection, inappropriate use of licences and unfair competition, all of which complicate the relation between operators and other parties.

When these events are compared against the characteristics of turbulence (Ansoff, 1979; Gueguen 1997), this study concludes that the industry studied was affected by the aforementioned phenomenon during the first decade of this century. After confirming the presence of turbulence in the mobile telephony industry, the study explores how companies addressed this situation, and the process is described below.

\subsection{Information gathering, analysis and interpretation}

To study the relationship of coevolution between turbulence and strategic behaviour, information from the recent past is required. Therefore, primary source information (available public financial information, i.e., financial statements) and sectoral information (trade union and periodical publications, i.e., newspapers and magazines) was gathered, and interviews with senior executives, government officers, trade union directors, researchers and consultants in mobile telephony - the key stakeholders - related to the selected organisations within industry were conducted for the study. Environmental turbulence, and coevolution were the analysis categories.

\section{Case Analysis}

This section includes the results of the analysis based on the empirical studies. For this purpose, the section describes each company, followed by an analysis based on the proposal of turbulence management by means of a coevolutionary relationship.

\subsection{América Móvil (Comcel)}

Comcel is a wireless telecommunications company that provides services such as mobile telephony, added value, telematics, carriers. The company was founded in February 1992. From its foundation until 2000, the company used a differentiation strategy focused on low level segments, intending to distinguish itself with product characteristics, market characteristics, and response time to customers.

In late November 2000, América Móvil S.A group, a Mexican company, became Comcel's main shareholder. With its arrival, Comcel adjusted its strategic behaviour to focus not only on prepaid customers but also on all socio-economic strata. Moreover, the company began to differentiate distribution channels and to use creative and innovative marketing communications to improve customer relations. Additionally, the company built alliances with the aim of implementing an inventory that guaranteed equipment replacement (Arbin, Holmberg and Jönsson, 2006; Santamaría, 2009, Gamboa and Otero, 2009; Flores Roux, 2009).

Environmental changes led Comcel to develop a broad network of alliances with mass media and major department stores, with the aim of achieving higher levels of market recognition. The company complemented these alliances by using exclusive distributors with long-term contracts. With the information gathered through different sources, Comcel implemented a business model that helped it achieve and consolidate a leadership position in the industry. The advantage of being the first player, the use of its rivals' strategic errors, commercial strategy, product development, financial management, management of supplies and management of corporate governance are the pillars of Comcel's strategy.

The strategies implemented to face turbulence changed the industry because they modified the business model with regard to distribution. Along with improved technology, the services offered also changed, such as the mass use of text messages and then social networks later, both of which led to new patterns of use among customers. In the 10 years considered in this study, the company went from 1 million to 29 million users. The company's market share grew from $45.6 \%$ to $65.8 \%$, improving its financial results. In 2000 , Comcel experienced a loss of $\$ 230$ million, whereas in 2010 , its profits reached $\$ 1,150$ million.

\subsection{Bellsouth}

Bellsouth is a U.S. company that began operating in Colombia in 2000. In 2001, the company decided to unify these operations and market its services under the Bellsouth brand. At that time, Bellsouth offered its services to businesses, 
families, students and individuals in general. Then, the company implemented a differentiation strategy mainly aimed at working with business customers that emphasised corporate post-pay. In 2003 and facing the arrival of a new PCS (Personal Communication Services) competitor, Bellsouth adjusted its strategy towards seeking increased market share. On the one hand, the company invested in CDMA (code division multiple access) technology to expand its portfolio and provide value-added services. Therefore, it designed plans for different types of customers characterised by a range of gradually decreasing prices. On the other hand, the company reinforced marketing campaigns, emphasising the advantages of mobile - as opposed to traditional - telephony. In addition, it created temporary promotions aimed to attract more customers, retain existing customers and increase consumption. These promotions were advertised through direct marketing with users and in the mass media, such as radio, television and billboards. The company also created a customer loyalty programme that rewarded customers with minutes if they expressed an interest in changing operators. To attract new customers, Bellsouth developed an advertising campaign that presented customers with tickets, electrical appliances and entertainment kits. In 2004, Bellsouth sold its operations in Latin America to Telefónica de España, which assumed service provision in Colombia.

\subsection{Telefónica Móviles-Movistar}

The company began operating in Colombia in 2004. At that time and according to Viana-Baptista (2004), the company undertook certain strategic changes aimed at ascending to industry leadership. Therefore, the company focused on gaining and exploiting economies of scale to negotiate better prices with equipment suppliers, provide quality service, better support and greater coverage. Facing the consolidation of Comcel, the company adjusted its differentiation strategy to assist not only corporate customers but also prepaid customers. This strategy involved offering a wide range of high-end equipment, a greater concern for providing superb customer service and full-time technical support.

Over time, Movistar focused on market and product development strategies. Regarding market development strategy, the company entered in new regions, expanded into rural areas and strengthened supply in new segments. This strategy implied an investment in second- and third-generation technology. With regard to product development strategy, the company provided plans according to each user's needs and income. The company's marketing campaigns aimed to encourage the use of the product, promoted a regular use, facilitated recall and publicised new applications. Arbi, Holmberg, and Jonsson (2006) find that the company implemented strategic changes that focused on the customer, which entailed that its business model would be based on five elements: quality, innovation, operational excellence, leadership, and communication with corporate identity.

Towards 2008 and as a result of environmental dynamism, the company signed strategic agreements with other Colombian Telecommunications companies, such as Colombia Telecomunicaciones S.A. E.S.P. and Telefónica Móviles Colombia S.A. These agreements aimed to jointly exploit commercial business and strengthen technological convergence to provide customers with packaged services.

In summary, company operations in the country can be shown to have contributed to the industry growth. The number of users registered by Telefónica amounted to 2.08 million, and the company's net profit in 2003 was 42 billion pesos. During the seven years that followed the Bellsouth acquisition, its users increased by 7.9 million and reached 10 million users in 2010, which was almost five times the number of users registered at the time of the acquisition. Thus, the company's market share reached $22 \%$.

\subsection{Colombia Móvil (Ola-Tigo)}

Colombia Móvil S.A. ESP is a company that operates in the field of Personal Communication Services (PCS). Formed in 2003, the company provides mobile telephony services in Colombia. It was created by the merger of the main public services and telecommunications companies in Colombia. The company entered the industry with a cost leadership strategy, offering the lowest prices in the market. This strategy was supported by third-generation networks and a wide distribution network, which led to the lowest costs in the industry. The price per minute was US\$0.015, whereas the rest of the operators offered an average of US $\$ 0.15$. In three months, the company reached more than 620,000 users, which represented $10 \%$ of the market. This event broke a record because the company became the operator with the largest number of GSM activations at that time.

This strategy modified the industry's broader settings, making an impact on sector growth, changing the communication habits of users and forcing regulators to implement new measures to protect both competitors and users. This growth, however, led to a series of problems for the company involving network capacity, customer service, inventory shortage, and billing problems and led the company to close its stores for a short period to search for solutions 
and to stock the stores with new equipment to meet demand. Thereafter, complaints of poor mobile coverage increased, generating market loss, problems in growth opportunities and financial loss over the years. To rectify this situation, the company searched for a strategic partner. By 2006, MillicomInternacional Cellular became the new major shareholder. This Swedish company, headquartered in Luxembourg and with a presence in numerous African, Asian and Latin American markets, operates under the TIGO brand.

The company's corporate strategy is supported by a low-cost model, massive distribution, and a focus on the prepaid segment. Moreover, the strategy applies a broad sales force and strong marketing that aims to expose the gaps of other operators. The results achieved by the company in recent years have been the function of implementing a business model oriented at mass markets, offering leadership in prices, coverage and accessibility, a strategy known as the "Three A's": Affordable, Accessible and Available.

This strategy is intended to provide customers with the best value for their money, offering innovative services at competitive prices that encourage subscribers to make greater top-ups. Over time and based on industry dynamism, Colombia Móvil has implemented a market development strategy to cover more territory and has also implemented a product development strategy to provide value-added services to low income sectors, supported by third-generation technologies. Towards the end of 2010, the company decided to make strategic alliances with companies interested in providing the mobile virtual network operator service. In this case, the alliance is with UFF - Móvil, which was slated to begin start operations in 2011.

As a result of the strategies implemented to face turbulence, which affected the environment by creating a coevolutionary spiral, the company managed to improve its financial results. In its first year of operations, the company suffered a loss of $\$ 190$ million, and it did not achieve its first profits until 2010. Its market share at the end of the decade reached $11.5 \%$, providing service to 5.2 million users.

\section{Case Analysis}

During the first decade of the $21^{\text {st }}$ century, the mobile telephony industry in Colombia experienced a state of turbulence. To properly manage this turbulence, companies modified their strategies in response to environmental changes, which led to high price competition, continuing development of new products, strong marketing campaigns, and continuing technological innovation. As a result of these adjustments in strategic behaviour, the companies increased their users and their income as a consequence. The service portfolio increased, the first mobile phones with mobile access to the Internet arrived, text message service spread widely, $3 G$ networks were developed, changes in the distribution models were implemented, and price competition increased.

The industry changed its managing method, forcing regulators to implement new regulations with the aim of protecting users and companies themselves, and of avoiding situations of unfair competition or monopoly. These changes led to new turbulence conditions and the subsequent response of the companies. These activities demonstrate a coevolutionary process - and not merely a feedback relationship - between both parties. Through their own experiences, the companies understood that they could modify environmental conditions. Therefore, turbulence would not be a threat but an opportunity for improvement.

At present, the mutual adaptation process continues and the stakeholders of the industry continue to present strategic changes, which subsequently generate direct or indirect effects on the environment. The only change detected is that there is no evidence of turbulence at present. Although there is uncertainty, the conditions that define dynamism and complexity have not appeared. Below, the document presents a detailed description of some effects of the relationship between a turbulent environment and the strategic behaviour of an industry.

\subsection{Coevolution due to economic factors}

During the period under study, the conditions of the economy directly affected the industry studied. Mobile telephony service demand changed based on economic conditions and on performance of indicators such as devaluation, level of employment, GDP growth. These fluctuations led operators to make decisions focused on increasing market share. Therefore, they resorted to adjustments in management and development methods, implementing strategies of expansion as well as external and cooperative development. To protect users and guarantee free competition, regulators implemented measures related to pricing issues, tax creation, the reassignment of electromagnetic bands, customer service, control of dominant position, etc., which affected both the demand and behaviour of the industry. 


\subsection{Coevolution due to technological factors}

A second relationship of coevolution has its starting point at the development of new technological platforms, which will allow the consolidation of digital technology. This coevloutionary relationship led operators to invest to increase their capacity in networks and in third-generation technologies, intending to provide plans that include value-added services that operate through the Internet.

The offer of new plans led to growth in the number of users, who gradually replaced landline telephone service with mobile telephony. The users also changed their patterns of use, using less voice traffic and making more use of text messages and social networking. As a result of these changes, the economy benefited from sectorial GDP growth, which led regulators to implement measures to protect users. Thus, technological progress affected product development and generated changes in social, regulatory and economic conditions.

\subsection{Coevolution due to political factors}

Another coevolutionary relationship showed a starting point in the change of political (regulatory) aspects of the industry. It began when the government stipulated the entrance of a third company into the industry (a PCS operator). Aware of the upcoming competition, the operators created new sales offers intended to satisfy user needs and consolidate their market presence. They undertook investments of close to 250 million dollars each to upgrade their networks.

When the new operator appeared, the industry changed because the new company offered lower prices, a different technological platform and a range of mobile phones never offered before in the country. These actions led to intensified rivalry and a rapid growth in the number of users, broadly disseminating the service into the low-income segments and increasing the prepaid modality, as a result. The entrance of a new operator also increased the income of suppliers, and landline telephone service lost more ground.

This situation led to significant changes in the general environment. New regulations were generated, particularly with regard to prices, interconnection charges between traditional operators and the PCS operator with regard to customer service, and changes in the operational conditions of radio communication (trunking). The users broadly disseminated the use of text messages and social networks as an alternative form of communication, using less voice traffic. Finally, with regard to the economy, the GDP of the industry experienced a substantial growth; and the new jobs generated by this growth contributed to the stability of the economy.

\subsection{Coevolution due to social factors}

In addition to the above, some of the events related to the socio-demographic component generated coevolutive relations. To the extent that individuals adjusted their communication needs as a result of the development of the Internet and the consolidation of social networks, the industry had to adjust their product portfolios. The operators provided new plans highlighting those applications that facilitated communication through social networks, text messages and data transfer, which led to an increase in demand, which directly affects the industry's GDP growth. Moreover, regulators implemented new measures to supervise the new products and protect users, creating new effects on operators' behaviour.

\subsection{Coevolution in regulatory aspects}

With regard to regulatory aspects that generate coevolution in an industry, continuous regulatory modifications were undertaken during the period under study, which led companies to adjust their strategic behaviour. Some of these regulations were passed to achieve industry growth, control operators, protect users, implement new technologies, set new taxes, and control prices. In other cases - and as a result of the industry's dynamism and the entrance of new operators and new business models - the rules of the market obligated regulators to modify existing regulations to protect the industry in general.

\section{Conclusions}

The situation studied indicates the presence not only of turbulence but also of coevolutionary processes between the environment and companies. These processes are confirmed by the appearance of certain characteristics addressed by Lewin and Volberda (1999), such as reciprocity, simultaneity, multilevel and multidirectional causalities, and learning. In 
terms of indicators, the companies individually were not the only entities to achieve growth; the industry also achieved a sustainable growth. For example, at the beginning of the decade, there were 2.2 million users, an income per telephony service of $\$ 1,102$ million and a coverage of 5 lines per 100 inhabitants. After 10 years of turbulence and coevolutionary processes, the number of lines reached 44.7 million, the operators' income reached $\$ 1,102$ million in 2010 , and as for coverage, 96 individuals out of 100 used the service.

In this case, the economy of the country consolidated through the mobile telephony business, new business were developed, and incomes resulting from taxes on consumption contributed to the generation of income for the country. There was also a cultural transformation since mobile telephony replaced landline telephone service. New international operators entered the market with new investments.

Coupling between the organisation and the turbulent environment led businesses to interact more with new sectors in implementing their business models. In this case, the mobile telephony operators joined other sectors to face the turbulence and to generate new products and services. Product sales are undertaken in major department stores, alliances with the financial sector are signed, content generation companies appear, etc.

The coevolutionary effect is present at multiple levels - both within the organisation and between businesses exhibiting a multilevel nature. This situation was detected because the companies performed adjustments in different areas - in marketing, in their relation with the community, in the financial area, etc. - when searching for new strategies to face turbulence. Many of these adjustments responded to governmental demands regarding technological and regulatory matters, such as regulations to protect customers and the implementation of new technologies.

Thus, the different areas of businesses reciprocally coevolve in the presence of a change in the general or specific environment. The process of mutual adaptation among businesses and environment is influenced by the level of knowledge and by experiences accumulated over time. Each operator made decisions based on previous events that may have appeared as a threat to the industry.

\section{References}

Abatecola, G. (2014). Research in organizational evolution. What comes next?. European Management Journal, 32(3), 434-443. Ansoff, I (1965). Corporate strategy: An analytic approach to business policy for growth and expansion. New York: McGraw Hill. Ansoff, I (1979). Strategic Management. London: MacMillan.

Barnett, W.P., \& Hansen, M. (1996). The Red Queen in Organizational Evolution. Strategic Management Journal, 17 (Summer Special Issue), 139-157.

Baum, J. A., \& Singh, J. V. (1994). Organizational niches and the dynamics of organizational mortality. American Journal of Sociology, 346-380.

Breslin, D. (2014a). Calm in the storm: Simulating the management of organizational co-evolution. Futures, 57, 62-77.

Breslin, D. (2014b). What evolves in organizational co-evolution?. Journal of Management \& Governance, 1-23.

Caldart, A., \& Ricart, J. (2006). Corporate Strategy in turbulent Environments: Key Roles of the Corporate Level. Barcelona, Spain: IESE Business School - University of Navarra.

Chakravarthy, B. (1997). A New Strategy Framework for Coping with Turbulence. Sloan Management Review, 38(2), 69-82.

Dess, G., \& Beard, D. (1984). Dimensions of organizational task environments. Administrative Science Quarterly, 29(1), 52-73.

Eisenhardt, K., \& Galunic, D. (2000). Coevolving: At last, a way to make synergies work. Harvard Business Review, 78, 91-101.

Emery, F., \& Trist, E. (1965). The Causal Texture of Organizational Environments. Human Relations, 18 (21), 21-32.

Flier, B., Bosch, F. A, \& Volberda, H. W. (2003), Co-evolution in Strategic Renewal Behaviour of British, Dutch and French Financial Incumbents: Interaction of Environmental Selection, Institutional Effects and Managerial Intentionality. Journal of Management Studies, 40: 2163-2187.

Galbraith, J. R. (1973). Designing complex organizations. Addison-Wesley Longman Publishing Co., Inc.

Grant, R. M. (2003). Strategic planning in a turbulent environment: evidence from the oil majors. Strategic management journal, 24(6), 491-517.

Gueguen, G. (1997). Face aux turbulences, l'entreprise doit-elle être réactive? Propos de réflexion. Vlème conférence de l'AlMS. Montreal: HEC.

Gueguen, G. (2001). Environnement et management stratégique des PME: le cas du secteur Internet. Doctorat en sciences de gestion. Université Montpellier.

Head, T. (2005). Structural Changes in turbulent Environments: A Study of Small and Mid-Size Chinese Organizations. Journal of Leadership \& Organizational Studies, 12(2), 82-93.

Hung, K. P., \& Chou, C. (2013). The impact of open innovation on firm performance: The moderating effects of internal R\&D and environmental turbulence. Technovation, 33(10), 368-380.

Huygens, M., Baden-Fuller, C., Van den Bosch, F., \& Volberda, H. (2001). Coevolution of Firm Capabilities and Industry Competition: Investigating the Music Industry 1877-1977. Organization Studies, 22(6), 971-1101.

Kauffman, S. (1995). At home in the universe: The search for the laws of self-organization and complexity. Oxford University Press. 
Khandwalla, P (1976-1977). Some top Management styles, their context and performance. Organizations and Administrative Sciences, 7(4), 21-51.

Khandwalla, P. (1972). Environment and its impact on the organization. International Studies of Management and Organization, 2(3), 297-313.

Lampel, J., \& Shamsie, J. (2003). Capabilities in Motion: New Organizational Forms and the Reshaping of the Hollywood Movie Industry*. Journal of Management Studies, 40(8), 2189-2210.

Lewin, A., \& Volberda, H. (2003). The future of organization studies: Beyond the selection adaptation debate. Oxford, England: Oxford University Press

Lewin, K., \& Volberda, H. (1999). Prolegomena on coevolution: A framework for research on strategy and new. Organizations Science, 10(5), 519-534.

Liu, Y. (2013). Sustainable competitive advantage in turbulent business environments. International Journal of Production Research, 51(10), 2821-2841.

Park, Y; Hong, P (2012). Building network capabilities in Turbulent Competitive Environments. CRC Press.

Pontikes, E. G., \& Barnett, W. P. (2016). The Coevolution of Organizational Knowledge and Market Technology. Forthcoming, Strategy Science.

Porter, T. B. (2006). Coevolution as a research framework for organizations and the natural environment. Organization \& Environment, 19(4), 479-504.

Ramírez, R., \& Selsky, J.W. (2016). Strategic Planning in Turbulent Environments: A Social Ecology Approach to Scenarios, Long Range Planning, 49(1), 90-102.

Rivera, H. (2010). Cambio estratégico y turbulencia. Revista Facultad de Ciencias Económicas: Investigación y Reflexión XVIII (1).

Schmitt, A., Barker, V. L., Raisch, S., \& Whetten, D. (2015). Strategic Renewal in Times of Environmental Scarcity. Long Range Planning.

Selsky, J., Goes, J., \& Baburoglu, O. (2006). Contrasting Perspectives of Strategy Making: Applications in 'Hyper' Environments. Organization Studies, 28(1), 71-94.

Stead, J. G., \& Stead, W. E. (2013). The Coevolution of Sustainable Strategic Management in the Global Marketplace. Organization \& Environment, 26(2), 162-183.

Stieglitz, N., Knudsen, T., \& Becker, M. C. (2016). Adaptation and inertia in dynamic environments. Strategic Management Journal, $37(9), 1854-1864$.

Su, Z., Peng, J., Shen, H., \& Xiao, T. (2013). Technological capability, marketing capability, and firm performance in turbulent conditions. Management and Organization Review, 9(1), 115-137.

Terreberry, S. (1968). The Evolution of Organizational environments. Administrative Science Quarterly, 12(4), 590-613.

Tsai, K. H., \& Yang, S. Y. (2014). The contingent value of firm innovativeness for business performance under environmental turbulence. International Entrepreneurship and Management Journal, 10(2), 343-366.

Van den Bosch, F.A.J., Volberda, H., \& de Boer, M. (1999). Coevolution of Firm Absorptive Capacity and Knowledge Environment: Organizational Forms and Combinative Capabilities, Organization Science, 10(5), 551-568.

Wang, G., Dou, W., Zhu, W., \& Zhou, N. (2015). The effects of firm capabilities on external collaboration and performance: The moderating role of market turbulence. Journal of Business Research, 68(9), 1928-1936.

Wilden, R., \& Gudergan, S. P. (2014). The impact of dynamic capabilities on operational marketing and technological capabilities: investigating the role of environmental turbulence. Journal of the Academy of Marketing Science, 1-19.

Wu, Q., He, Q., Duan, Y., \& O'Regan, N. (2012). Implementing dynamic capabilities for corporate strategic change toward sustainability. Strategic Change, 21(5-6), 231-247.

Yin, R. K. (2013). Case study research: Design and methods. Sage publications.

Zhang, J., Jiang, Y., \& Zhu, M. (2015). Perceived environmental turbulence, strategic orientations and new product success: a comparative study of SMEs and large manufacturing exporters. Journal of Advances in Management Research, 12(1).

Zuñiga-Vicente, J., \& Vicente-Lorente, J. (2006). Strategic Moves and organizational Survival in Turbulent Environments: The case of Spanish Banks (1983-97). Journal of Management Studies, 43(3), 485-519. 